\title{
The Polemics of Shantarakshita and Kamalashila with the Mimamsakas on the Existence and Properties of Atman in "Tattvasamgraha-panjika"*
}

\author{
Lev Titlin \\ RAS Institute of Philosophy \\ Peoples' Friendship University of Russia \\ 6 Miklukho-Maklaya Str. \\ Moscow, Russia \\ E-mail: titlus@gmail.com
}

\begin{abstract}
The article considers the philosophical polemics between Buddhism and Mimamsa on the problem of the existence and properties of the self as it is given in the chapter "The Polemics with the Mimamsakas on Atman" of the section "Atmapariksha" (lit. "The Study of Atman") of "Tattvasamgraha" of Shantarakshita (the 8th century) with the commentary "Panjika" of Kamalashila. According to the Mimamsakas, atman has a form of consciousness (caitanya) and exclusive and inclusive nature. Exclusive - as the seat of satisfaction and dissatisfaction, etc., which are mutually exclusive states, inclusive - as a sequence of consciousness, essentiality, good qualities, etc. Shantarakshita criticizes the position of the Mimamsakas, revealing contradictions in their internal philosophical logic.
\end{abstract}

Keywords-Shantarakshita; Kamalashila; 'Tattvasamgraha'; 'Panjika'; atman; purusha; self; no-self; anatman; soul; denial of self; subjectivity

\section{INTRODUCTION}

Shantarakshita 1 (the name is sometimes interpreted as Shantirakshita - the protector of shanti, peace) (years of life according to different data 705-762, 750/770-770/810, 680$840,725-784)$, one of the greatest Buddhist philosophers [4] [5] [6] [7]. He played a decisive role in the establishment of Buddhism in Tibet; his works are included in the Tibetan Buddhist canon (Tengyur). He belonged to the YogacharaSvatantrika-Madhyamaka school2. For his activities he was awarded the title of acarya-bodhisattva ("teacherBodhisattva"). His most important work is "Tattvasamgraha" ("Collection of Essential Problems", or "Compendium of Categories", hereafter TS), a monumental Buddhist philosophical encyclopedia, in 26 chapters of which the

*The work was carried out within the framework of the grant of the RSF No 16-18-10427 "Indian Philosophy in the Context of the History of World Philosophy: The Problem of the Translation of Meanings".

For more on Shantarakshita, see article of V.P. Androsov and also books [1] [2] [3].

For more in detail about Yogachara and Madhyamaka, see articles of Androsov V. P. and Ignatovich A. N. and also books of Lepakhov S. Yu. and Chatterjee A. K. [8] [9] [10] [11]. doctrines of all the main Indian philosophical schools (Samkhya, Nyaya, Vaisheshika, Mimamsa, Lokayata, Yoga, Vedanta, and Jainism and Buddhism of other schools). For a long time, it was believed that the original Sanskrit text TS was irretrievably lost. So, S.Ch. Vidyabhushana considered, in particular, still in 1978 [12]. However, as it turned out, in 1893 the famous German Sanskritist Johann-Georg Buhler found its incomplete Sanskrit text in the repository of the monastery in Jaisalmer (Rajasthan, India). Later S.D. Dala found the full Sanskrit text of the TS with the commentary of Kamalashila "Panjika" ("Tattvasangraha-panjika", hereafter TSP). It was he who was published in Baroda in 1926 by $\mathrm{E}$ Krishnamacharya [13]. Subsequently, the text was issued by S.D. Shastri [14]. To the English language, the TSP was translated by G. Jha. [15]. Separate chapters were translated into Chinese, Japanese and German, three chapters were translated into Russian: "Ishvara-pariksha" by V. P. Androsov, "Pratyakshalakshana-pariksha" by V.G. Lysenko and "Anumana-pariksha" by N. A. Kanaeva (two editions) [16]. One of the chapters of the section on the doctrine of atman - "Atmavada" - was published in the article [17].

"Tattvasamgraha" was written, according to $\mathrm{B}$. Bhattacharya, until 743, from the point of view of Western Indologists - ca. 760 [18] [19].

The TS came to us along with the Sanskrit commentary of his pupil Kamalashila (ca. 700-750). Kamalashila belonged to the school of Svatantrika-Madhyamaka, which criticized certain positions of the Yogacara-SvatantrikaMadhyamaka.

The main value of "Tattvasamgraha" is that it consistently reproduces the teachings of all the main Indian philosophical schools in a polemical presentation, many of which would otherwise have been completely lost. In turn, Kamalashila gives the names of philosophers, who are not indicated in the text, in accordance with the existing tradition, and even quotes from their writings. Thus, "Tattvasamgraha" covers polemics on key philosophical issues for almost three centuries, ending with the era of Uddyotakara (about 6th-7th century). 
The treatise can be divided into three sections: ontological (chapters 1-15), epistemological (chapters 16-20) and soteriological (chapters 21-26).

The critique of the self-concept that we are interested in is included in the ontological section of the work, namely to the 7th chapter ("Atmapariksja," lit. "The Study of Atman"), in which the author successively analyzes the concepts of Nyaya-Vaisheshika, Mimamsa, Samkhya, Jainas, AdvaitaVedanta and the Vatsiputriyas ("heretical" school of Buddhism, which admitted the existence of the selfpudgala3).

The considered passage is devoted to a discussion between the Buddhists and the Mimansakas on the question of the existence of atman. We will review the section devoted to the polemic with the Mimamsakas based on our own translation (the first time from Sanskrit into Russian, will be published in [23].) The translation was made according to the edition [24]. For more on the polemics between Buddhism and Bharmanism on atman please see [25].

\section{THE NATURE OF ATMAN ACCORDING TO MiSAMSA}

The Mimamsakas argue that atman possesses the nature of consciousness (caitanya), which is identical to buddhi (intellect) ${ }^{4}$, and also has inclusive and exclusive nature. By exclusive nature he mutually exclusive character of such states of consciousness as pain, pleasure, etc. is meant. Under inclusive nature they mean that it is at the same time an intellect, a substance and a being that serve cognition, that is, inclusion, not exclusion. Consciousness by Mimamsakas is understood as the only possible form of buddhi-intellect. Kamalashila asks how consciousness can have a mutually exclusive nature of inclusion and exclusion? The opponents respond by the argument of the Samkhyas: just as a snake has a folded shape and a straight-line shape, it still retains its snake nature, just as atman retains its nature of consciousness, despite the coming states of pain and pleasure. At the same time inclusive nature is not completely preserved (as the Nayayikas believe), when there is an exclusive, it sort of "falls into the background." Then Kamalashila asks why opponents do not adhere to the theory of absolutely exclusive nature, as the Buddhists do, that is, that there are only states of consciousness that are completely destroyable, or the theory about absolutely inclusive nature, as do the Nayayikas? The answer is that if there was an absolute destruction of atman, then the destruction of what was done and the appearance of what was not done would happen. And if, on the contrary, atman was always in the same form, then the experience of suffering and pleasure would be impossible. With the absolute destruction of atman, the destruction of the produced action would be, since an actor could not obtain the results of his actions, and also the taste of the fruits of the

Pudgala is a quasi-subject, a person, whose existence was recognized by the Pudgalavada school. For more on pudgala please see our article and also the articles of V. G. Lysenko and V. K. Shokhin [20] [21] [22].

Unlike the Samkhyas, for which consciousness belongs to atman (purușa), buddhi as the Cosmic Intellect is the product of Prakṛti. deeds would be no longer produced by atman who performed the deed. Kamalashila objects: if atman possesses two natures at the same time, then also one nature will act, and the other will partake of the fruits. This will also lead to the absurdity of "destroying what has been done and the appearance of what has not been done." Opponents answer to this that the properties of atman to be an "agent" and an "enjoyer" do not depend on its inclusive and exclusive nature and belong to atman itself, staying throughout all states of consciousness.

\section{How IS THE EXISTENCE OF ATMAN ESTABLISHED?}

According to the Mimamsakas, the existence of atman is proved by the presence of awareness expressed in such sentences as "I have comprehended it," "I comprehend it." Thanks to the same awareness, according to the Mimamsakas, the doctrine of the non-self, held by the Buddhists, is refuted. The Mimamsakas believe that the concept of the self-included in the sentence "I know" represents the knower. This cognizer can be either atman or an absolutely fleeting cognition (idea, jñāna). If the object of the concept of the knower is atman, then everything is certain, if this is instantaneous knowledge, then everything becomes entangled. For example, what cognitive moment is the object of the concept of "I", which appears in the form "it was I who knew this thing in the past, and this I know it now" - a) the past b) the present c) existing in the form of a sequence? If option a) is accepted, then the past cognitive moment may be the object of expression "it was I who knew this thing in the past", but not of the statement "I know it now". If option b) is accepted, then the opposite situation arises. Both variants a) and b) are irrelevant. Option c) is also not possible, because it is the series of a sequence of variants a) and b): the sequence cannot comprehend the thing in the past, because its part is in the present, but also cannot comprehend and the thing in the present, because is not an entity, but that which is not an entity cannot be a cognizer from the point of view of the Mimamsakas. Thus, it is established that where there is this ahamkara (the concept of "I"), which must be different from such an ephemeral concept, there exists atman in its eternal form. Kamalashila agrees with opponents that the expression "I know" represents the knower, because the verb "I know" is obviously the concept of a person who realizes knowledge. However, considering the possible alternatives, what cognitive moment is the object of this concept of "I", he suggests not three, as Shantarakshita, but four options, adding the option that the object of it are two points - the past and the future at the same time. However, this option is impossible, because both moments were individually refuted - they cannot simultaneously know the object in the past, but also cannot cognize it in the present.

\section{THE ETERNITY OF ATMAN}

According to the Mimamsakas, the fact that atman is eternal is proved by the fact that the knower is the object of the "I"-consciousness, both in the past and in the future. All the "I"-consciousnesses of the past and the present must have the same object because these "I" -consciousnesses refer to 
the one cognizer and belong to the same sequence, that is, for example, to a hypothetical person, Devadatta, like any other cognition too.

The first objection of the Buddhists is that if consciousness is regarded as eternal and single, then cognition (buddhi) must also be considered as having the same nature. However, this contradicts the teachings of opponents. So, for example, Shabara (Mimamsaka, the author of "Bhashya"), asserts that cognition is momentary. Jaimini also says that "perception is a cognition produced by contact with a thing", but it cannot be produced if it is eternal. This also contradicts the perception process, because in his process, various cognitions arise and disappear. Kamalashila raises the question of how, in that case, if cognition is single, there are differences in such cognitions as cognition of color, cognition of taste, etc., to which opponents respond that differences come from objects. Kamalashila again objects: if consciousness were eternal and single, it would grasp everything together and at the same time, since there is nothing that would depend on any difference. Opponents in response give several analogies. The first is a comparison with fire, which, though always of a burning nature, does not burn all things or at any time. The second is a comparison with a pure mirror or crystal, which reflect only the object that lies before it. Similarly, atman, although possessing the nature of eternal consciousness and being omnipresent, perceives color and other things only when they are under the influence of an invisible force (fate) in bodies and these things are given to them through sensory organs such as the eye, etc., and not when they are outside the bodies. Kamalashila gives an objection: how, then, is this knowledge known as ephemeral? Opponents answer that cognition is regarded as ephemeral only because of the nature of the functioning of the sense organs, such as the eye, which demonstrate to atman color and other things.

The Mimamsakas contend that cognition is a property of atman, therefore, the difference of knowledge should not lead to differences in atman, which is only a substance that has its cognitions as qualities. Kamalashila replies that in fact words such as pratyaya, caitanya, buddhi (intelligence, knowledge), jñāna (knowledge) are synonymous, and the verbal distinction between them does not lead to differences in the nature of things.

If knowledge is always in the form of comprehension of all things, how is it that it does not always comprehend all things at once? And that cognition on which sound is imposed must be the same cognition that comprehends the taste and color, that is, it must comprehend them simultaneously, and between these cognitions there should be no differences. If this is not so, then opponents will have to admit that cognition has differences.

Then Shantarakshita proceeds to refute the analogy with fire. He says that the example with fire is not accepted by both sides, because just as cognition cannot possess the nature of comprehension of all things, fire does not in fact always manifest itself in the form of burning things that are burned, because in this case it would incinerate the whole world, because it would always be in contact with these things, like the burning thing, which is in actual fact in contact with the flame. In fact, only when the fire is in close proximity to the burning thing, it can be considered as burning, so there is no burning of all things at the same time.

\section{How Are the States of Consciousness Possible?}

Further, says Kamalashila, if opponents believe that atman have always the same form (nature), then such different states as "happiness", etc. are impossible. If they recognize these different states, then atman does not always have always the same form, because the same thing cannot have such opposite properties as difference and nondifference. Opponents believe that this objection was answered by Kumarila, who argues in "Shlokavarttika" that the eternally unchangeable atman, concerning which it is asserted that there are no differences in it, depending on the difference in the states of happiness, unhappiness and others, even passing through these states, does not stop its properties to be conscious, to be a substance, essence, and others, such as being cognizable, being correctly cognized, being an active agent. Even when a new state occurs, the previous state, for example, the state of happiness, is not completely destroyed, it is dissolved in the general property of atman, so that a new state can arise. If so, says Kamalashila, then why is happiness a state of unhappiness is not being felt? The answer is that they dissolve. As long as the state of happiness is in its own form, another state, a state of unhappiness, does not arise, it remains dissolved in the general property of atman, such as being conscious, being a substance, etc., which continues in all states, and thus makes possible the emergence of the next state of unhappiness.

\section{WHAT IS THE OBJECT OF AHAMKĀRA?}

Shantarakshita goes on to prove that the statement that the "I"-conception (ahamkāra) in the proposition "I know" perceives the cognizer, is unproven (not accepted by both parties). In reality, the concept of "I" has no real basis. It arises from the beginningless seed of the vision of being, and only in certain places. Kamalashila explains that "the vision of being" is a vision of the existing body, the seed of this vision is the power of predispositions (vasanas), in certain places - in the six-species human body. If we recognize that atman is the basis of the concept of "I," then the question arises, why does not this concept also apply to another atman? Opponents may respond that this is due to limitations imposed by the force of the things. Then the Buddhists can answer that this concept arises only in relation to some internal objects, but not to all. If the opponents say that if such a restriction is accepted, how then is the absence of the real basis of "I" conception is being proved? Shantarakshita replies that if the concept of "I" had an eternal thing as the basis, then all "I"-conceptions would arise simultaneously, because their acting cause in its perfect form would always be available. Its basis also could not exist at all without basis, because this would lead to absurdity. Nor can we say that the concept of "I" is single, since it is obvious that there are many of them since they arise only from case to case. For example, in the state of deep sleep, intoxication or swoon, the "I"-consciousness does not exist, and in other states it is 
experienced. Consequently, opponents vainly ask the question of the basis of the concept "I". If it had a noneternal basis, then all the "I"-conceptions would also be clearly given, as visual and other cognitions, since they would directly grasp the specific individuality of a particular thing. Thus, the concept of "I" is totally unfounded and is an illusion arising from the vision of the body.

\section{CONCLUSION}

Thus, since it is proved that the "I"-consciousness has no basis, there cannot be any knowing person who is the object of this "I"-consciousness. Once it is shown that the concept of atman, or "I", is devoid of any real object, therefore, there cannot be any cognitive subject to which this concept applies. Consequently, the existence of atman itself is not proved.

So, we can summarize and conclude that in the "Discussion with the Mimamsakas" from "Atmapariksha" of "Tattvasamgraha" of Shanarakshita, two opposing logics are faced - the non-substantive logic of the Buddhists and the substantive logic of the Mimamsakas.

Shantarakshita's main argument in the dispute with the Mimamsakas is that, in his opinion, there is a contradiction between the concept of the eternal and unchanging atman and its properties as a cognizing and acting subject. Indeed, Buddhists here proceed from experience that says that all our knowledge is transient and changeable, and we do not find within ourselves any eternal and unchangeable self. Even if it was, it could not have anything to do with the particular changeable facts of the psyche and the moments of consciousness. Thus, Shantarakshita concludes, the concept of unchanging atman as a reality is only an illusion of the psyche, which is not confirmed by any real experience and enters into a logical contradiction with the facts.

But the Buddhists understand the self ("I") as a stream of dharmas, or truly existing elements, phenomena, moments of consciousness, the psyche, divided into five categories (aggregates, skandhas), namely: "[group of material] sensuality (rūpa), [group] of sensations (vedana), representations (samjnā), [group] of karmic factors (saṃskāra), [group] of perceptions (vijñāna). Anātmavāda (denial of the self in Buddhism) consists in the direct denial of the predicate "atman," or "I," the self, with respect to these five groups that constitute the psychophysical complex of a person.

As opposed to the Buddhists, the Mimamsakas consider the self a substance, an independently existing entity endowed with certain properties, such as unchangeable consciousness (caitanya), activity, the ability to enjoy the fruits of the deeds.

We can conclude that on the whole Shantarakshita successfully refutes all the arguments proposed by Kumarila Bhatta in "Shlokavarttika", mainly revealing the internal contradiction in the very concept of atman in Mimamsa.

At the same time, we must state that the arguments of both the Brahmanists and the Buddhists are relevant, mainly only within their own systems, and the main subject of contradictions in the question of the self is not so much its acknowledgement or denial but the dissimilarity of ontological and logical paradigms of disputing parties.

If we talk about the main arguments that the opponents adduce, they are reduced, for the most part, to finding internal contradictions in the positions of the opposite party. Such arguments prove to be very effective against Mimamsa, the concept of atman in which sometimes looks contradictory from the point of view of the logic of common sense (mainly two ways of treating the self - as a transcendent atman and as an embodied soul do not fit into everyday logic). In any case, almost all the arguments of opponents tend to be based on their own philosophical logic. In general, it can be assumed that Purva-Mimamsa is building a special ontological and epistemological system, which in principle is accessible to criticism only on the basis of its own positions. The Buddhist system in general is irrefutable, it builds a special, non-substantive ontology and offers a completely original language for describing reality, in which quite different laws operate than in the systems of the Brahmanists. Because of this, it turns out to be "impenetrable" for their arguments.

\section{REFERENCES}

[1] V.P. Androsov, Shantarakshita // Philosophy of Buddhism Encyclopedia / Stepanyants M.T., Ed. Vostoschnaya literatura, Moscow, 2011. - 1050 p. (in Russ.) P. 799-800.

[2] V. G. Lysenko, N. A. Kanaeva, Sāntarakșita and Kamalaśîla on the instruments of valid cognition. M.: RAS Institute of Philosophy, 2014 $-295 \mathrm{p}$.

[3] J. Blumenthal, Sāntarakșita, Rgyal-tshab Dar-ma-rin-chen. The ornament of the middle way: a study of the Madhyamaka thought of Śāntarakșita : including translations of Śāntarakșita's Mādhyamakālaṃkāra (The ornament of the middle way) and Gyeltsab's dbU ma rgyan gyi brjed byang (Remembering "The ornament of the middle way"). - Snow Lion Publications, 2004. - 381 p.

[4] Śāntarakșita. Tattvasaṃgraha, with the comment. Pañjikā of Shrī Kamalaśîla // Gaekwad`s Oriental series / Ed. E. Kṛ̣ṇ̄āmācārya. With a Foreword by B. Bhattacharyya. Baroda. In 2 vols.

[5] L. N. Joshi Studies in the Buddhistic Culture of India (During the 7th and 8th centuries A. D.). Delhi, 1977. - 497 p.

[6] H. Nakamura, Indian Buddhism. A Survey with bibliographical notes. Tokyo, 1980. $-423 \mathrm{p}$.

[7] L. S. Kawamura, Buddhism, Mādhyamika: India and Tibet // Routledge Encyclopedia of Philosophy, Version 1.0, L.: Routledge, 1998

https://www.rep.routledge.com/articles/thematic/buddhismmadhyamika-india-and-tibet/v-1 (дата обращения 10.10.2017).

[8] V. P. Androsov, Madhyamaka // Philosophy of Buddhism: Encyclopedia / Stepanyants M.T., Ed. Vostoschnaya Literatura, Moscow, 2011. - 1050 p., pp. 420-422.

[9] A. N. Ignatovich, Madhyamaka // Philosophy of Buddhism: Encyclopedia / Stepanyants M.T., Ed. Vostoschnaya literatura, Moscow, 2011. - 1050 p., pp. 422-425.

[10] S. Yu. Lepekhov, The Philosophy of the Madhyamikas and the Genesis of the Buddhist Civilization. Ulan-Ude: Izd-vo BNTs SO RAN, 1999. - 237 p.

[11] A. K. Chatterjee, The Yogacara Idealism / Tr. D. Ust'iantsev. Shechen: 2004. - 268 p.

[12] S. C. Vidyabhușaṇa, A History of Indian Logic: Ancient, Mediaeval and Modern Schools. Delhi, 1978. - 648 p. 
[13] Śāntarakṣita. Tattvasaṃgraha, with the comment. Pañjikā of Shrī Kamalaśíla // Gaekwad`s Oriental series / Ed. E. Kṛ̣ṇāāmācārya. With a Foreword by B.Bhattacharyya. Baroda, 1926. In 2 vols.

[14] Tattvasamgraha of Ācārya Śāntarakșita with the commentary Pañjikā of Śrī Kamalaśîla. Critical Edited by Swāmi Dvārikāda Śāstrī. In two vols. Bauddha Bharati, Varanasi, 1968.

[15] Jha G. (Tr.), The Tattvasangraha of Shantaraksita With the Commentary of Kamalashila . Vol. 1. - Delhi: Motilal Banarsidass, 1986. -739 p. P. 159.

[16] V. G. Lysenko, N. A. Kanaeva, Śāntarakṣita and Kamalaśíla on the instruments of valid cognition. M.: Institut filosofii RAN, 2014. - 295 p.

[17] L. I. Titlin, The Polemics with the Nyaya-Vaisheshikas on the Question of the Existence of Self in the "Tattva-samgraha" of Shantarakshita // E-journal Philosophy of Thought. - URL: http://enotabene.ru/fr/article_20948.html (accessed 10.10.2017). DOI: 10.25136/2409-8728.2017.10.20948. pp. 139-163.

[18] H. Krasser, On the Relationship between Dharmottara, Śāntarakṣiita and Kamalaśîla // Tibetan Studies. Proceedings of the 5th seminar of the International Association of Tibetan Studies, Narita, 1989. Narita, 1992, p. 157.

[19] E. Frauwallner, Landmarks in the History of Indian Logic // WZKSO. 1961. Bd. 5. S. p. 143.

[20] L.I. Titlin, The Notion of the Self in Pudgalavada Buddhism // Istoriya filosofii № 17. M. : Izd-vo IF RAN, 2013, pp. 15-40.

[21] V.G. Lysenko, Pudgala // Philosophy of Buddhism: Encyclopedia / Stepanyants M.T., Ed. Vostoschnaya literatura, Moscow, 2011. 1050 p., pp. 566-567.

[22] V.K. Shokhin, Vatsiputriya // Philosophy of Buddhism: Encyclopedia / Stepanyants M.T., Ed. Vostoschnaya literatura, Moscow, 2011. 1050 p., pp. 208-210.

[23] L. I. Titlin, The Polemics of Shantarakshita and Kamalashila with the Mimansakas on the Existence and Properties of Atman in "Tattvasamgraha-Panjika" (Translation of an Excerpt) // Gumanitarii: aktual'nye problemy gumanitarnoi nauki i obrazovaniya. - Saransk, Izdatelskij tsentr Istoriko-sotsiologicheskogo instituta Mordovskogo gosudarstvennogo universiteta im. N. P. Ogareva, 2018.

[24] Tattvasaṃgraha of Ācārya Śāntarakṣita with the commentary Pañjikā of Śrī Kamalaśīla. Critical Edited by Swāmi Dvārikāda Śāstrī. In two vols. Bauddha Bharati, Varanasi, 1968.

[25] L. I. Titlin, The Problem of the Self in the Polemics Between Buddhism and Brahmanism: The History of the Study of the Question // Philosophy and Culture, 2013. No. 1, pp. 29-49. etc., 1978. (1st ed. $-1921) .-648$ p., p. 324. 